\title{
'Spontaneous aneurysm of left testicular artery with an anomalous origin': detection of a rare entity on CT
}

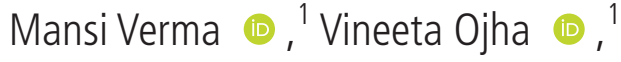 \\ Sheragaru Hanumanthappa Chandrashekhara $0^{0},{ }^{2}$ Sanjeev Kumar ${ }^{1}$
}

${ }^{1}$ Department of Cardiovascular Radiology and Endovascular Interventions, All India Institute of Medical Sciences, New Delhi, Delhi, India

${ }^{2}$ Radiodiagnosis, All India Institute of Medical Sciences, New Delhi, Delhi, India

\section{Correspondence to} Dr Sanjeev Kumar; sanjeevradio@gmail.com

Accepted 10 December 2020

D) Check for updates

(c) BMJ Publishing Group Limited 2021. No commercial re-use. See rights and permissions. Published by BMJ.

\begin{tabular}{l}
\hline To cite: Verma M, Ojha V, \\
Chandrashekhara SH, \\
et al. BMJ Case Rep \\
2021;14:e240456. \\
doi:10.1136/bcr-2020- \\
240456 \\
\hline
\end{tabular}

\section{DESCRIPTION}

A 29-year-old man presented with intermittent mild dull aching non-radiating epigastric pain of 3 months duration. No aggravating factors were present and the pain was relieved on analgesic medications. There was no history of fever, constitutional, urological or sexual symptoms. Also, there was no history of trauma or surgery and the laboratory investigations for infectious, inflammatory and serological markers were negative. He underwent ultrasonography which revealed a vascular lesion anterolateral to aorta and on Doppler evaluation, the lesion showed arterial wave form in the anechoic component. With the provisional diagnosis of an aneurysm, CT angiography (CTA) was done to further characterise its exact origin and extent and to rule out any other aneurysm. Review of CTA images revealed anomalous origin of left testicular artery from hilar segment of left renal artery. (figure 1B,C) In addition, a peripherally thrombosed fusiform aneurysm measuring approximately $1.7 \times 1.7 \mathrm{~cm}$ was noted in the proximal part of left testicular artery. (figure $1 \mathrm{~A}-\mathrm{C}$ ) No calcification or mass effect on pelvicalyceal system was seen. Imaging did not reveal involvement of any other vascular territory. There was no family history of

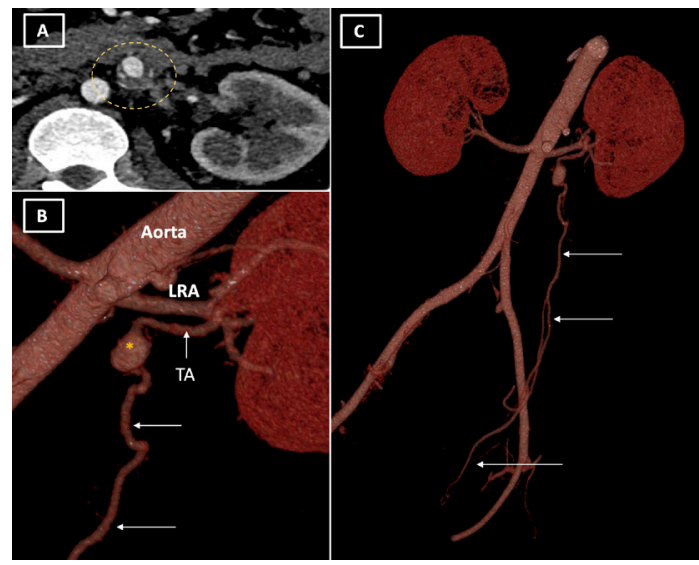

Figure 1 Axial image (A) shows a peripherally thrombosed aneurysm (dotted yellow circle). Volume rendered image $(B, C)$ depicting anomalous origin of left testicular artery (white arrows in $B, C$ ) from hilar segment of left renal artery with presence of aneurysm in proximal part (yellow * in B). LRA, left renal artery; TA, testicular artery.

\section{Learning points}

Aneurysms and pseudoaneurysms of testicular artery are rare and are mostly seen after trauma or infection.

- Spontaneous occurrence of aneurysm from anomalous testicular artery near its origin is rare.

- CT angiography plays an important role in depicting such anomalies of origin or aneurysms of the vessels.

aneurysm or any other predisposing factor like intravenous drug abuse or immunocompromised state to raise suspicion for infected aneurysm. Considering the above, a diagnosis of exclusion of 'idiopathic spontaneous aneurysm' was made.

Aneurysms and pseudoaneurysms of testicular artery are rare and have been described in literature secondary to trauma, infection and inflammation. ${ }^{1}$ Almost all of these have been reported in intratesticular location with patients presenting with painless scrotal swelling or scrotal pain. ${ }^{1}$ To the best of our knowledge, spontaneous occurrence of aneurysm from anomalous testicular artery in such a high location has not been reported. In our case the anomalous origin of left testicular artery from left renal artery can be classified as Type II according to classification by Ciçekcibaşi et al. ${ }^{2}$ Due to rarity of this disease entity no standard treatment exists. Surgical excision is usually performed in cases of aneurysm growth or in symptomatic cases. Since the gonadal artery is arising from the hilar segment of the left renal artery, endovascular treatment would be technically challenging. In this case, since the aneurysm was small and the patient had mild nonspecific pain, he was kept on follow-up. Patient was symptom-free at 6 months and follow-up Doppler at 6 months revealed no increase in the overall size of the aneurysm.

Contributors MV: wrote the manuscript. VO: prepared the images. SHC: proofread the manuscript. SK: edited the manuscript.

Funding The authors have not declared a specific grant for this research from any funding agency in the public, commercial or not-for-profit sectors.

Competing interests None declared.

Patient consent for publication Obtained.

Provenance and peer review Not commissioned; externally peer reviewed. 


\section{Images in...}

\section{ORCID iDs}

Mansi Verma http://orcid.org/0000-0002-3313-4350

Vineeta Ojha http://orcid.org/0000-0003-4371-5615

Sheragaru Hanumanthappa Chandrashekhara http://orcid.org/0000-0001-9924-

$853 X$

\section{REFERENCES}

1 Zicherman JM, Mistry KD, Sarokhan CT, et al. Ct angiography, sonography, and MRI of aneurysm of the testicular artery. AJR Am J Roentgenol 2004;182:1088-9.

2 Ciçekcibaşi AE, Salbacak A, Seker M, et al. The origin of gonadal arteries in human fetuses: anatomical variations. Ann Anat 2002;184:275-9.

Copyright 2020 BMJ Publishing Group. All rights reserved. For permission to reuse any of this content visit https://www.bmj.com/company/products-services/rights-and-licensing/permissions/

BMJ Case Report Fellows may re-use this article for personal use and teaching without any further permission.

Become a Fellow of BMJ Case Reports today and you can:

- Submit as many cases as you like

- Enjoy fast sympathetic peer review and rapid publication of accepted articles

- Access all the published articles

- Re-use any of the published material for personal use and teaching without further permission

\section{Customer Service}

If you have any further queries about your subscription, please contact our customer services team on +44 (0) 2071111105 or via email at support@bmj.com.

Visit casereports.bmj.com for more articles like this and to become a Fellow 